\title{
Sodium intake and high blood pressure among adults on caloric restriction: a multi-year cross-sectional analysis of the U.S. Population, 2007-2018
}

4

Jorge Andrés Delgado-Ron, ${ }^{1}$ Patricio López-Jaramillo, ${ }^{2}$ and Mohammad Ehsanul Karim ${ }^{1,3}$

1. School of Population and Public Health, University of British Columbia, Vancouver, BC, Canada.

2. Instituto Masira, Medical School, Universidad de Santander (UDES), Bucaramanga, Colombia.

3. Centre for Health Evaluation and Outcome Sciences (CHEOS), St. Paul's Hospital, Vancouver, BC, Canada.

Corresponding author:

Jorge Andrés Delgado-Ron, School of Population and Public Health, University of British Columbia. 2206 East Mall Vancouver, BC Canada, V6T $1 Z 3$.

Phone: +1 6047269954

Email: andres@delgado.ec; jorge.delgadoron@ubc.ca 
medRxiv preprint doi: https://doi.org/10.1101/2020.12.27.20248919; this version posted January 2, 2021. The copyright holder for this preprint (which was not certified by peer review) is the author/funder, who has granted medRxiv a license to display the preprint in perpetuity.

It is made available under a CC-BY 4.0 International license .

\section{$1 \quad$ Abstract and Keywords}

2

3
Aim: Small studies have shown reduced sodium sensitivity of blood pressure in obese adolescents on caloric restriction. However, no study at the population level has studied such an effect. We aimed to explore the association between mean daily sodium intake and prevalent hypertension among a nationally representative sample of U.S. adults on caloric restriction who participated in the National Health Examination and Nutrition Survey over the last twelve years.

Methods and Results: We used a design-based regression model to explore the association between sodium intake and prevalent hypertension. We also conducted sensitivity analyses using multiple imputation chained equations and propensity score matching. We also measured the effect of a binary exposure derived from two widely recommended thresholds of sodium intake: 2.3 and 5.0 grams per day. Among 5,756 individuals, we did not detect any significant association between increased sodium and the odds of hypertension (OR: 0.97; CI 95\%: 0.90; 1.05). All our sensitivity analyses are consistent with our main findings.

Conclusion: Our findings suggest that people on caloric restriction-a component of healthy weight loss-would see no benefit in reducing sodium intake to lower blood pressure. These results highlight the need to explore new population-specific strategies for sodium intake reduction, including new dietary prescription approaches to improve dietary adherence and reduce the risk associated with sodium-deficient diets.

Keywords: Hypertension; Dietary Sodium; Blood Pressure; Weight Loss; Caloric Restriction 
medRxiv preprint doi: https://doi.org/10.1101/2020.12.27.20248919; this version posted January 2, 2021. The copyright holder for this preprint (which was not certified by peer review) is the author/funder, who has granted medRxiv a license to display the preprint in perpetuity.

It is made available under a CC-BY 4.0 International license.

\section{Introduction}

2

3

4

Hypertension causes more death and disability than any other risk factor globally, ahead of smoking, high glucose, and obesity. Nearly 10.4 million deaths worldwide were attributable to elevated blood pressure in 2017. ${ }^{1}$ Ambard and Beaujard theorized a potential association between salt consumption and hypertension as early as 1904 . However, contradictory evidence from observational studies using low-salt diets led to an intense debate that lasted more than a century. ${ }^{2}$ Only recently, well-designed clinical trials provided reliable answers. The Dietary Approaches to Stop Hypertension-Sodium (DASH-Na) trial concluded that "blood pressure can be lowered ... by reducing the sodium intake." ${ }^{3}$ Long-term cohort studies support the DASH-Na trial findings. ${ }^{4}$

The precise mechanisms that cause dietary sodium to modulate blood pressure levels are not well defined, which often translates to uncertainty about who would benefit from such interventions. Past studies have shown the role of specific modifiers like ethnicity, even at the molecular level. ${ }^{5}$ However, we know much less about the role of energy balance-the equilibrium between calories consumed and calories burned through physical activity ${ }^{6}$-as a modifier of "salt sensitivity" of blood pressure.

Energy balance is arguably a more critical modifier than diet or exercise on their own. After all, we reach metabolic tipping points that enable our bodies to regulate blood pressure through the additive interaction of energy intake and energy expenditure. ${ }^{7,8}$ Current studies lack this holistic understanding and, as a result, present somehow conflictive evidence. For instance, a reanalysis of the DASH-Na data found less energy intake associated with increased salt sensitivity. ${ }^{9}$ Similarly, a community-based study in China found that participants in the highest quartile of physical activity had reduced salt sensitivity compared to the lowest quartile. However, there was not a linear association across quartiles. ${ }^{10}$ 
medRxiv preprint doi: https://doi.org/10.1101/2020.12.27.20248919; this version posted January 2, 2021. The copyright holder for this preprint (which was not certified by peer review) is the author/funder, who has granted medRxiv a license to display the preprint in perpetuity.

It is made available under a CC-BY 4.0 International license .

$$
\text { Caloric restriction and fitness are recommended to prevent or control hypertension. }{ }^{11,12} \text { The }
$$

current European and American hypertension guidelines recommend a reduced sodium intake on top of that. ${ }^{13,14}$ However, it is not clear if patients would benefit from reducing sodium in their diet once they are on an energy deficit. Caloric restriction—a negative energy balance-reduces blood pressure levels through improved insulin sensitivity, reduced adiposity, and reduced sympathetic activity, independent of reaching an ideal body weight. ${ }^{15,16}$ These mechanisms might also play a role in modulating the salt sensitivity of blood pressure. ${ }^{12,17}$ Studies that induced weight loss have modified the relationship between sodium and blood pressure. However, they used small samples and are outdated. $^{16,18}$

In the present work, we used a design-based regression model to explore the association between mean daily sodium intake and prevalent hypertension among U.S. adults on caloric restriction in the National Health Examination and Nutrition Survey (NHANES) from 2007 to 2018.

\section{Methods}

\section{Data source, Design, and Study Population}

We used publicly available data from NHANES, a cross-sectional four-stage stratified cluster complex survey, representative of the non-institutionalized United States population. NHANES gathers lifestyle and medical information, along with biological samples and a physical examination. Readers can find relevant description design and sampling procedures associated with this survey elsewhere. ${ }^{19}$ The study complies with the Declaration of Helsinki and it is covered by item 7.10.3 in the University of British Columbia’s Policy 89 on studies involving human participants and Article 2.2 in the Tri-Council Policy Statement Ethical Conduct for Research Involving Humans. 
medRxiv preprint doi: https://doi.org/10.1101/2020.12.27.20248919; this version posted January 2, 2021. The copyright holder for this preprint (which was not certified by peer review) is the author/funder, who has granted medRxiv a license to display the preprint in perpetuity.

It is made available under a CC-BY 4.0 International license.

\section{Analytic sample and study variables}

We included adults aged 20-79 years from six two-year cycles (2007-2018) with an energy

deficit of at least -350 calories per day. We chose this cut-off to correct potential underreporting from

self-reported dietary data. ${ }^{20}$ We derived energy balance from its two essential components: energy

input (mean daily intake) and energy output (basal metabolic rate plus physical activity). ${ }^{6}$ The basal

metabolic rate was calculated using the revised Harris-Benedict equations. ${ }^{21}$ Self-reported weekly

vigorous and moderate physical activity was transformed into daily metabolic equivalents following

NHANES' suggested scores. ${ }^{22}$ NHANES derives the total daily intake from two 24-hour recall

interviews, 3 to 10 days apart, using a validated instrument to reduce recall bias. ${ }^{23}$ We did not exclude participants with invalid or missing answers for physical activity; instead, we used their basal metabolic rate as total output.

We excluded pregnant women and participants with body mass index (BMI) below 18.5 (malnutrition) or an active thyroid pathology due to inherent metabolic differences in these patients. Adults over the age of 80 were excluded because their age is not publicly available due to privacy concerns. We also excluded people who reported a "much less than usual" intake during either interview.

The primary outcome was hypertension, a binary variable indicating one of the following: self-reported use of antihypertensive medication or systolic hypertension (mean systolic blood pressure $\geq 130 \mathrm{mmHg}$ ) or diastolic hypertension (diastolic blood pressure $\geq 80 \mathrm{mmHg}$ ). ${ }^{11}$ Individuals without a second valid measurement for either systolic (SBP) or diastolic blood pressure (DBP) were excluded to avoid measurement error.

The exposure was self-reported mean consumption of sodium (grams per day) as a continuous measure. Two additional binary variables were derived for our sensitivity analyses (described later). 
medRxiv preprint doi: https://doi.org/10.1101/2020.12.27.20248919; this version posted January 2, 2021. The copyright holder for this preprint (which was not certified by peer review) is the author/funder, who has granted medRxiv a license to display the preprint in perpetuity.

It is made available under a CC-BY 4.0 International license .

1 Other covariates included demographic data (age, gender, education, income, and ethnicity), pre-

2 existing diseases (diabetes and obesity), and smoking. ${ }^{24}$ We excluded "Refused," "Don't know," and

3 "Missing" values for demographic variables. However, for diabetes, we required respondents to

4 provide a definitive "Yes." The details of the analytic data creation process are shown in Figure 1.

5

6

7 the variables under consideration. Given we already restricted the sample by energy balance, we

[Figure 1]

Figure 2 depicts our hypothesized causal diagram describing the causal relationships among minimized bias adjusting for age, diabetes, education, ethnicity, gender, energy expenditure, BMI, and smoking status based solely on Pearls' backdoor criterion. ${ }^{25}$ Serum sodium and the reninangiotensin-aldosterone system (unmeasured) were assumed mediators. Other unmeasured variables include alcohol consumption and fat accumulation.

\section{[Figure 2]}

\section{Primary Analysis}

We compared individuals' characteristics by hypertension status (yes/no) using surveyfeatured $t$-tests for continuous variables and the Rao-Scott F-adjusted $\chi 2$ test for categorical variables. ${ }^{26}$ We combined the survey weights from our six cross-sectional subsamples following NHANES recommendations ${ }^{19}$ and built our design using all survey features, subsetting only the eligible sample. We estimated the Odds Ratio (OR) and respective confidence intervals (CI 95\%) using a design-based multivariate logistic regression (hereafter referred to as the 'outcome model'), adjusting for the variables selected based on Pearls' backdoor criterion as described above.

We probed interactions between sodium intake and the other covariates using Bauer's inferential and graphical techniques ${ }^{27}$ based on findings from the previous literature. ${ }^{9}$ Collinearity was 
medRxiv preprint doi: https://doi.org/10.1101/2020.12.27.20248919; this version posted January 2, 2021. The copyright holder for this preprint (which was not certified by peer review) is the author/funder, who has granted medRxiv a license to display the preprint in perpetuity.

It is made available under a CC-BY 4.0 International license .

1 assessed via variance inflation factors (VIF) and classified following the recommendations by

2 Belsley. $^{28}$

The goodness of fit for all models was evaluated using weighted ROC curves and the Archer-

4 Lemeshow test. ${ }^{29,30}$ All 95\% confidence intervals (CI) and Cox-Snell pseudo- $\mathrm{R}^{2}$ account for both the

5 survey design and day-to-day dietary intake variations. ${ }^{19,31,32}$

6 Sensitivity Analyses

\section{Missing data}

As missing completely at random assumption may not be realistic, we applied the multivariate

9 imputation by chained equation method. ${ }^{33,34}$ We imputed 20 datasets under the missing at random

assumption using all the variables from our primary analysis model as predictors for the imputation

model. Rubin's rules were used to pool the estimates together. ${ }^{34}$

We transformed the exposure in our outcome model to a binary variable. First, we used the

14 threshold of $\geq 2.3 \mathrm{~g}$ /day to classify exposure as "high" or "low," following the maximum sodium

15 intake recommendations in current European and American hypertension guidelines. ${ }^{13,14}$ Then, we

16 used a threshold of $\geq 5.0 \mathrm{~g} /$ day, the daily sodium intake recommended by the World Health

17 Organization, ${ }^{35}$ using the same specifications described below.

We performed the analysis with both the complete-case dataset and the imputed datasets,

pooling the estimates as described above. We also matched the probability of being exposed to "high"

or "low" sodium intake using propensity scores for both thresholds. We performed a 1:1 nearest

neighbour match (without replacement) on the propensity score's logit with a 0.2 calliper. ${ }^{36}$ We

modelled the exposure using our original covariates — cycle and survey features were also covariates

23 following Dugoff's method ${ }^{37}$ — to achieve adequate standardized mean difference balance (SMD < 
medRxiv preprint doi: https://doi.org/10.1101/2020.12.27.20248919; this version posted January 2, 2021. The copyright holder for this preprint (which was not certified by peer review) is the author/funder, who has granted medRxiv a license to display the preprint in perpetuity.

It is made available under a CC-BY 4.0 International license.

1 0.2). The survey-featured outcome model was used to estimate the population average treatment

2 effect from the matched subsample. Again, the exposure was binary ("high" vs. "low").

3 All statistical analyses were performed using $\mathrm{R} 4.0 .3 ;^{38}$ the code is available on request.

4 Results

$5 \quad$ Study sample characteristics

We evaluated a total of 5,756 individuals, representing a U.S. national population of

$753,036,129$. The weighted prevalence of hypertension in our sample was $42.6 \%$. On average,

8 hypertensive individuals were significantly more likely to be male, older, diabetic, and overweight or

9 obese. Hypertensive and non-hypertensive people also differed significantly in ethnicity and smoking

10 history, but not education or daily total energy expenditure. Sodium intake did not significantly differ

11 by hypertension status (Table 1$)$.

\section{Association between mean daily sodium intake and prevalent hypertension}

14 A one-gram increase in daily sodium intake did not significantly correlate with higher odds of

15 hypertension in the U.S. population on caloric restriction. The estimate was imprecise around the null

16 in both the crude $(\mathrm{OR}=0.98,95 \%$ CI: $0.93 ; 1.03)$ and adjusted models (Table 2$)$. We did not find any

17 significant interaction between the exposure and other covariates. Multicollinearity was "near weak"

18 for all independent variables $(\mathrm{VIF}<2.5)$. 
medRxiv preprint doi: https://doi.org/10.1101/2020.12.27.20248919; this version posted January 2, 2021. The copyright holder for this preprint (which was not certified by peer review) is the author/funder, who has granted medRxiv a license to display the preprint in perpetuity.

It is made available under a CC-BY 4.0 International license .

1 Sensitivity analysis

2 Multiple imputations for missing data

Data for moderate and vigorous physical activity was missing for $30 \%$ of the sample. Other sampling variables with lower proportions of missing data were calorie intake (9\%), height (8\%), and the derived BMI (8\%). Model variables with missingness were mean sodium intake $(9 \%)$ and

6 education (40.8\%). Each imputed dataset contained approximately 6,326 observations. The estimate

7 and confidence intervals were equal to that of the primary analysis (OR=0.97, 95\% CI: $0.90 ; 1.05)$

8 (Table 2).

9 Sodium intake of $\geq 2.3 \mathrm{~g} / \mathrm{day}$

10 Consuming 2.3 grams of sodium per day or more was not significantly associated with higher 11 hypertension odds in either the complete-case or imputed data analyses. Although both estimates

12 found a different effect, they were imprecise around the significance threshold. Hence, we failed to

13 find an association (Table 3).

The final propensity score for the probability of being exposed to higher amounts of sodium was estimated using age, gender, ethnicity, education, BMI (categorical), history of diabetes, history

16 of smoking, energy expenditure, and survey features. After propensity-score matching, a total of

172,808 participants - representing a U.S. population of 24,340,468 - were matched. Matching reduced the SMD to $<0.1$ for all covariates, except for total daily energy expenditure (SMD =0.27). Our

19 outcome model corrected any remaining imbalances. The results, again, could not support an association between exposure and outcome (OR=0.99, 95\% CI: 0.77; 1.27) (Table 3). 
medRxiv preprint doi: https://doi.org/10.1101/2020.12.27.20248919; this version posted January 2, 2021. The copyright holder for this preprint (which was not certified by peer review) is the author/funder, who has granted medRxiv a license to display the preprint in perpetuity.

It is made available under a CC-BY 4.0 International license .

1 Sodium intake of $\geq 5.0 \mathrm{~g} / \mathrm{day}$

When the threshold for "high" sodium intake was 5 grams per day or more, the estimates did

3 not change significantly for either the complete-case or the multiple imputation pool estimated. The

4 lack of association, however, was accompanied by wider confidence intervals (Table 4).

We estimated the probability of being exposed to "high" sodium levels using the same model

6 for both thresholds. A total of 926 participants—representing a U.S. population of 9,559,626-were

7 matched by their propensity score. The SMD for all covariates was balanced $(<0.17)$. The binary

8 outcome model showed no association between exposure and outcome (Table 4).

\section{[Table 4]}

\section{Discussion}

\section{Main findings}

Our analysis of a multi-year nationally representative sample of U.S. adults on caloric restriction did not detect any significant association between increased sodium consumption levels and the odds of hypertension (OR: 0.97; CI 95\%: 0.90; 1.05). Our survey-featured logistic regression was adjusted by age, gender, ethnicity, education, BMI, diabetes, smoking, and total daily energy expenditure. Several sensitivity analyses yielded similar results, including those that analyzed two widely recommended sodium intake thresholds ( $\geq 2.3$ and $\geq 5.0$ grams per day). These results cement the need to target low-sodium interventions appropriately given its associated risks. ${ }^{39,40}$

Very few studies had been able to identify a representative sample of participants on caloric

21 restriction, commonly identified through healthy weight loss. Our findings suggest that people on

22 caloric restriction would see no benefit in reducing sodium in their diet to lower blood pressure. 
medRxiv preprint doi: https://doi.org/10.1101/2020.12.27.20248919; this version posted January 2, 2021. The copyright holder for this preprint (which was not certified by peer review) is the author/funder, who has granted medRxiv a license to display the preprint in perpetuity.

It is made available under a CC-BY 4.0 International license .

1 These findings apply to the general U.S. adults and other populations with similar characteristics. Our

2 findings align with previous reports in obese adolescents, who lost their "sensitivity of blood pressure

3 to sodium" following a 20 -week intervention to lose weight (through caloric restriction). ${ }^{18}$

Caloric restriction lowers blood pressure levels independent of other factors; it decreases body

5 fat and, consequentially, increases insulin sensitivity. ${ }^{41}$ Insulin modulates the renal absorption of

6 sodium. As a result, people on caloric restriction excrete more sodium than those in a caloric surplus,

7 which might explain the loss of sodium sensitivity in these patients. ${ }^{42}$ Such effects can be seen within

8 hours of fasting and had been recently hypothesized as mechanisms that regulate blood pressure

9 levels in healthy and sick individuals. ${ }^{17,43,44}$ While these are acute effects, other cardiometabolic

10 benefits of caloric restriction appear to be long-lasting. ${ }^{15}$ We highlight the need for a tailored

11 approach for blood pressure control in this specific subpopulation. Laxer sodium intake

12 recommendations for these patients could help mitigate the potential low adherence to a low sodium

13 diet and its associated adverse effects (e.g. increased risk of death). ${ }^{39,40,45}$ They could also reduce the

14 complexity of dietary interventions and increase their palatability, which is paramount to improving

15 adherence and achieving successful weight reduction. ${ }^{46}$

Strengths and limitations

Our study benefited from using a population-level sample, with an adequate representation of people from diverse ethnicities, ages, and socioeconomic characteristics. Our analysis used survey features, which allowed us to generalize our findings to all the non-institutional U.S. adult population going through a healthy weight loss. We restricted our sample to participants on caloric restriction,

21 therefore addressing the ambiguities of metabolically healthy obese patients and lean people who

22 exhibit obese-like characteristics (dyslipidemia, altered inflammatory profile, and increased fat cell

23 size). ${ }^{47,48}$ Rarely do hypertension studies account for such ambiguity. Our findings were robust under 
medRxiv preprint doi: https://doi.org/10.1101/2020.12.27.20248919; this version posted January 2, 2021. The copyright holder for this preprint (which was not certified by peer review) is the author/funder, who has granted medRxiv a license to display the preprint in perpetuity.

It is made available under a CC-BY 4.0 International license.

1 the missing at random assumption and to adjustments to the exposure to recommended intake levels

2 by American and European current guidelines and the World Health Organization guidelines.

Our study has several limitations. We used self-reported data for energy intake, prone to measurement bias and underreporting. While our selected threshold ${ }^{20}$ for energy balance accounts for such underreporting, this measurement error is not systematic. We further tried to minimize bias by only including the observations marked as reliable by NHANES—providing a detailed description of each food, including the amount, additional ingredients, and eating occasions—and excluding all participants reporting a less than usual intake. NHANES interviewers also double-check to elicit forgotten foods, and the survey weights account for variation between weekends and weekdays. ${ }^{49}$ We also used self-reported sodium consumption instead of the 24-hour urinary collection 11 (considered by many as the gold standard). We made this decision based on two arguments. Firstly, the Automated Multiple-Pass Method employed by NHANES provides reliable sodium and intake measures. ${ }^{23}$ Secondly, the hypothesized underlying mechanism (increased sodium retention) requires us to measure intake and not excretion.

Self-reported data for moderate and vigorous activity is not as reliable as objectively measured 16 physical activity. ${ }^{50}$ If people reported more than 24 hours of physical and sedentary activity,

17 NHANES analysts set those values to missing. We dealt with this first with two methods. Firstly, we took a conservative sampling (including the BMR as total energy expenditure whenever data was not available meant that participants who reported high activity levels were considered sedentary).

20 Secondly, we used multiple imputations procedures under the assumption that these data, although 21 not missing at random, could be predicted using the available variables. ${ }^{33}$ Statistically, there were no 22 significant differences between the estimates obtained by either method. However, the direction of the 23 effect changed with multiple imputations in both thresholds. Such a change of direction might reflect 
medRxiv preprint doi: https://doi.org/10.1101/2020.12.27.20248919; this version posted January 2, 2021. The copyright holder for this preprint (which was not certified by peer review) is the author/funder, who has granted medRxiv a license to display the preprint in perpetuity.

It is made available under a CC-BY 4.0 International license .

1 the effect of the omitted physical activity in the complete-case sample. Nevertheless, the difference

2 was not statistically significant. Finally, our cross-sectional design did not allow us to establish a

3 temporal relationship between exposure and outcome. It's feasible for people to modify their diet to

4 cope with their disease.

\section{Conclusion}

6 Our findings showed that sodium intake was not associated with higher odds of hypertension

7 among the U.S. population on caloric restriction. Our results were robust to missing data and different

8 representations of the exposure, disputing a low-salt diet's benefits for people who achieve weight

9 loss and maintain it using caloric restriction. These results highlight the need to explore new

10 population-specific strategies for sodium intake reduction, including new dietary prescription

11 approaches that improve adherence and reduce the risk associated with deficient sodium diets.

\section{Disclosure}

13 Funding: none declared.

Conflict of interest: Dr. Karim reports grants from BC SUPPORT Unit, grants from Michael

15 Smith Foundation for Health Research, grants from Natural Sciences and Engineering Research

16 Council of Canada, personal fees from Biogen Inc., outside the submitted work. 
medRxiv preprint doi: https://doi.org/10.1101/2020.12.27.20248919; this version posted January 2, 2021. The copyright holder for this preprint (which was not certified by peer review) is the author/funder, who has granted medRxiv a license to display the preprint in perpetuity.

It is made available under a CC-BY 4.0 International license .

\section{References}

2 1. GBD 2017 Risk Factor Collaborators. Global, regional, and national comparative risk assessment of 84 behavioural, environmental and occupational, and metabolic risks or clusters of risks for 195 countries and territories, 1990-2017: a systematic analysis for the Global Burden of Disease Stu. Lancet (London, England) 2018;392:1923-1994.

6 2. DiNicolantonio JJ, O'Keefe JH. The History of the Salt Wars. Am J Med Elsevier Inc; 2017;130:1011-1014.

3. Sacks FM, Svetkey LP, Vollmer WM, Appel LJ, Bray GA, Harsha D, Obarzanek E, Conlin PR, Miller ER, Simons-Morton DG, Karanja N, Lin P-H, Aickin M, Most-Windhauser MM, Moore TJ, Proschan MA, Cutler JA. Effects on Blood Pressure of Reduced Dietary Sodium and the Dietary Approaches to Stop Hypertension (DASH) Diet. N Engl J Med Massachusetts STL, Wei L, Diaz R, Avezum A, Lopez-Jaramillo P, Lanas F, Mony P, Szuba A, Iqbal R, Medical Society; 2001;344:3-10. Determining Blood Pressure Fall With Salt Restriction in Black and White Hypertensives. Hypertension American Heart Association; 1998;32:820-824. 
medRxiv preprint doi: https://doi.org/10.1101/2020.12.27.20248919; this version posted January 2, 2021. The copyright holder for this preprint (which was not certified by peer review) is the author/funder, who has granted medRxiv a license to display the preprint in perpetuity.

It is made available under a CC-BY 4.0 International license .

1 for Nutrition; 2012;95:989-994.

2 7. Hinderliter AL, Babyak MA, Sherwood A, Blumenthal JA. The DASH diet and insulin sensitivity. Curr Hypertens Rep 2011;13:67-73.

4 8. Archer E, Lavie CJ, Hill JO. The Contributions of 'Diet' 'Genes' and Physical Activity to the Etiology of Obesity: Contrary Evidence and Consilience. Prog Cardiovasc Dis Elsevier Inc.; 2018;61:89-102.

7 9. Murtaugh MA, Beasley JM, Appel LJ, Guenther PM, McFadden M, Greene T, Tooze JA.

10. Rebholz CM, Gu D, Chen J, Huang J-F, Cao J, Chen J-C, Li J, Lu F, Mu J, Ma J, Hu D, Ji X,

11. Whelton PK, Carey RM, Aronow WS, Casey DEJ, Collins KJ, Dennison Himmelfarb C, DePalma SM, Gidding S, Jamerson KA, Jones DW, MacLaughlin EJ, Muntner P, Ovbiagele B, Smith SCJ, Spencer CC, Stafford RS, Taler SJ, Thomas RJ, Williams KAS, Williamson JD, Wright JTJ. 2017 ACC/AHA/AAPA/ABC/ACPM/AGS/APhA/ASH/ASPC/NMA/PCNA Guideline for the Prevention, Detection, Evaluation, and Management of High Blood Pressure in Adults: Executive Summary: A Report of the American College of Cardiology/American Heart Association Task. Hypertens (Dallas, Tex 1979) United States; 2018;71:1269-1324.

12. Lechner K, Schunkert H. Recommendations on sodium intake for cardiovascular health: conviction or evidence? Eur Heart J 2020;41:1-2. 
medRxiv preprint doi: https://doi.org/10.1101/2020.12.27.20248919; this version posted January 2, 2021. The copyright holder for this preprint (which was not certified by peer review) is the author/funder, who has granted medRxiv a license to display the preprint in perpetuity.

It is made available under a CC-BY 4.0 International license .

1 13. Jackson S, Cogswell M, Zhao L, Terry A, Wang C-Y, Wright J, Coleman King S, Bowman B,

Chen T-C, Merritt R, Loria, Catherine. Association Between Urinary Sodium and Potassium

Excretion and Blood Pressure Among Adults in the United States. Circulation American Heart Association; 2018;137:237-246.

14. Williams B, Mancia G, Spiering W, Agabiti Rosei E, Azizi M, Burnier M, Clement DL, Coca A, Simone G de, Dominiczak A, Kahan T, Mahfoud F, Redon J, Ruilope L, Zanchetti A, Kerins M, Kjeldsen SE, Kreutz R, Laurent S, Lip GYH, McManus R, Narkiewicz K, Ruschitzka F, Schmieder RE, Shlyakhto E, Tsioufis C, Aboyans V, Desormais I. 2018 ESC/ESH Guidelines for the management of arterial hypertension: The Task Force for the management of arterial hypertension of the European Society of Cardiology (ESC) and the European Society of Hypertension (ESH). Eur Heart J 2018;39:3021-3104.

15. Kraus WE, Bhapkar M, Huffman KM, Pieper CF, Krupa Das S, Redman LM, Villareal DT, Rochon J, Roberts SB, Ravussin E, Holloszy JO, Fontana L. 2 years of calorie restriction and cardiometabolic risk (CALERIE): exploratory outcomes of a multicentre, phase 2, randomised controlled trial. Lancet Diabetes Endocrinol 2019;7:673-683.

16. Tuck ML, Sowers J, Dornfeld L, Kledzik G, Maxwell M. The Effect of Weight Reduction on Blood Pressure, Plasma Renin Activity, and Plasma Aldosterone Levels in Obese Patients. $N$ Engl J Med Massachusetts Medical Society; 1981;304:930-933.

17. Brands MW. Role of insulin-mediated antinatriuresis in sodium homeostasis and hypertension. Hypertension 2018;72:1255-1262.

18. Rocchini AP, Key J, Bondie D, Chico R, Moorehead C, Katch V, Martin M. The Effect of Weight Loss on the Sensitivity of Blood Pressure to Sodium in Obese Adolescents. N Engl J Med Massachusetts Medical Society; 1989;321:580-585. 
medRxiv preprint doi: https://doi.org/10.1101/2020.12.27.20248919; this version posted January 2, 2021. The copyright holder for this preprint (which was not certified by peer review) is the author/funder, who has granted medRxiv a license to display the preprint in perpetuity.

It is made available under a CC-BY 4.0 International license .

1 19. Centers for Disease Control and Prevention (CDC). National Center for Health Statistics (NCHS). National Health and Nutrition Examination Survey Questionnaire. Dep. Heal. Hum. Serv. Centers Dis. Control Prev. 2020. https://wwwn.cdc.gov/nchs/nhanes/ (9 October 2020)

20. Archer E, Hand GA, Blair SN. Validity of U.S. Nutritional Surveillance: National Health and Nutrition Examination Survey Caloric Energy Intake Data, 1971-2010. PLoS One 2013;8:112.

21. Roza AM, Shizgal HM. The Harris Benedict equation reevaluated: resting energy requirements and the body cell mass. Am J Clin Nutr 1984;40:168-182.

22. Jetté M, Sidney K, Blümchen G. Metabolic equivalents (METS) in exercise testing, exercise prescription, and evaluation of functional capacity. Clin Cardiol 1990;13:555-565.

23. Rhodes DG, Murayi T, Clemens JC, Baer DJ, Sebastian RS, Moshfegh AJ. The USDA Automated Multiple-Pass Method accurately assesses population sodium intakes. Am J Clin Nutr 2013;97:958-964.

24. Ford ES, Cooper RS. Risk factors for hypertension in a national cohort study. Hypertension 1991;18:598-606.

25. Textor J, Zander B van der, Gilthorpe MS, Liśkiewicz M, Ellison GT. Robust causal inference using directed acyclic graphs: The R package ‘dagitty’. Int J Epidemiol 2016;45:1887-1894.

26. Rao JNK, Scott AJ. On chi-squared tests for multiway contingency tables with cell proportions estimated from survey data. Ann Stat JSTOR; 1984;12:46-60.

27. Bauer DJ, Curran PJ, Thurstone LL. Probing interactions in fixed and multilevel regression: Inferential and graphical techniques. Multivariate Behav Res 2005;40:373-400.

22 28. Belsley DA. Assessing the presence of harmful collinearity and other forms of weak data 
medRxiv preprint doi: https://doi.org/10.1101/2020.12.27.20248919; this version posted January 2, 2021. The copyright holder for this preprint (which was not certified by peer review) is the author/funder, who has granted medRxiv a license to display the preprint in perpetuity.

It is made available under a CC-BY 4.0 International license .

through a test for signal-to-noise. J Econom 1982;20:211-253.

2 29. Archer KJ, Lemeshow S. Goodness-of-fit test for a logistic regression model fitted using survey sample data. Stata J 2006;6:97-105.

4 30. Hocking TD. Weighted ROC analysis. 2017;1:1-2.

5 31. Koch GG, Freeman Jr DH, Freeman JL. Strategies in the multivariate analysis of data from complex surveys. Int Stat Rev Int Stat JSTOR; 1975;59-78.

7 32. Lumley T. Pseudo-R2 statistics under complex sampling. Aust New Zeal J Stat 2017;59:187194.

9 33. Sterne JAC, White IR, Carlin JB, Spratt M, Royston P, Kenward MG, Wood AM, Carpenter JR. Multiple imputation for missing data in epidemiological and clinical research: potential and pitfalls. BMJ 2009;338:b2393.

12 34. Zhang Z. Multiple imputation with multivariate imputation by chained equation (MICE) package. Ann Transl Med AME Publications; 2016;4:30.

14 35. World Health Organization. Guideline: sodium intake for adults and children. World Heal. Organ. Geneva: World Health Organization; 2012.

36. Austin PC. Optimal caliper widths for propensity-score matching when estimating differences in means and differences in proportions in observational studies. Pharm Stat 2011;10:150_ 161.

37. Dugoff EH, Schuler M, Stuart EA. Generalizing observational study results: applying propensity score methods to complex surveys. Health Serv Res Blackwell Publishing Ltd; 2014;49:284-303. 
medRxiv preprint doi: https://doi.org/10.1101/2020.12.27.20248919; this version posted January 2, 2021. The copyright holder for this preprint (which was not certified by peer review) is the author/funder, who has granted medRxiv a license to display the preprint in perpetuity.

It is made available under a CC-BY 4.0 International license .

1 38. R Core Team. R: A Language and Environment for Statistical Computing. Vienna, Austria; 2020.

39. McCarron DA, Geerling JC, Alderman MH. Urinary sodium excretion measures and health outcomes. Lancet Elsevier Ltd; 2019;393:1294-1295.

40. O’Donnell M, Mente A, Alderman MH, Brady AJB, Diaz R, Gupta R, López-Jaramillo P, Luft

41. Nicoll R, Henein MY. Caloric restriction and its effect on blood pressure, heart rate variability and arterial stiffness and dilatation: A review of the evidence. Int J Mol Sci 2018;19:1-18.

42. Nakano Y, Oshima T, Sasaki S, Higashi Y, Ozono R, Takenaka S, Miura F, Hirao H, Matsuura

43. Sigler MH. The mechanism of the natriuresis of fasting. J Clin Invest 1975;55:377-387.

44. Heyman SN, Bursztyn M, Szalat A, Muszkat M, Abassi Z. Fasting-Induced Natriuresis and SGLT: A New Hypothesis for an Old Enigma. Front Endocrinol (Lausanne) Frontiers Media

45. Messerli FH, Hofstetter L, Syrogiannouli L, Rexhaj E, Siontis GCM, Seiler C, Bangalore S. Sodium intake, life expectancy, and all-cause mortality. Eur Heart J 2020;

22 46. Åberg G, Edman G, Rössner S. Perceived hunger, palatability, and adherence: A comparison of 
medRxiv preprint doi: https://doi.org/10.1101/2020.12.27.20248919; this version posted January 2, 2021. The copyright holder for this preprint (which was not certified by peer review) is the author/funder, who has granted medRxiv a license to display the preprint in perpetuity.

It is made available under a CC-BY 4.0 International license.

high- and low-fat diets. Obes Res Clin Pract 2008;2:101-110.

2 47. Ding C, Chan Z, Magkos F. Lean, but not healthy: the 'metabolically obese, normal-weight' phenotype. Curr Opin Clin Nutr Metab Care England; 2016;19:408-417.

4 48. Stefan N, Häring H-U, Hu FB, Schulze MB. Metabolically healthy obesity: epidemiology, mechanisms, and clinical implications. Lancet Diabetes Endocrinol England; 2013;1:152-162.

6 49. Ahluwalia N, Dwyer J, Terry A, Moshfegh A, Johnson C. Update on NHANES dietary data: Nutr 2016;7:121-134.

50. Prince SA, Adamo KB, Hamel ME, Hardt J, Connor Gorber S, Tremblay M. A comparison of direct versus self-report measures for assessing physical activity in adults: A systematic review. Int J Behav Nutr Phys Act 2008;5. 
medRxiv preprint doi: https://doi.org/10.1101/2020.12.27.20248919; this version posted January 2, 2021. The copyright holder for this preprint (which was not certified by peer review) is the author/funder, who has granted medRxiv a license to display the preprint in perpetuity.

It is made available under a CC-BY 4.0 International license .

\section{Figure legends}

Figure 1. Flow chart of the analytic sample selection for testing the association between

3 sodium intake and high blood pressure among U.S. adults on caloric restriction aged 20-79, using data

4 from the National Health and Nutrition Examination Survey; cycles 2007-2008 to 2017-2018.

Figure 2. Directed acyclic graph for assessing the causal association between sodium intake

6 and elevated blood pressure. Considering our energy balance restriction, age, gender, ethnicity,

7 education, income, and total intake act as confounders. We achieved sufficient adjustment by

8 controlling age, diabetes, education, ethnicity, gender, energy expenditure, body mass index, and

9 smoking status. Fat accumulation, alcohol, and the renin-angiotensin-aldosterone system (RAAS) are

10 unmeasured variables. Serum sodium and RAAS are mediators. The figure was drawn using the web-

11 version of DAGitty. 
medRxiv preprint doi: https://doi.org/10.1101/2020.12.27.20248919; this version posted January 2, 2021. The copyright holder for this preprint (which was not certified by peer review) is the author/funder, who has granted medRxiv a license to display the preprint in perpetuity.

It is made available under a CC-BY 4.0 International license.

\section{Text tables}

2 Table 1. Participants characteristics by hypertensive status, U.S. adults who reported caloric restriction aged 20-79.

3 National Health and Nutrition Examination Survey (NHANES) 2007-2018.

\begin{tabular}{|c|c|c|c|}
\hline & $\begin{array}{l}\text { Non-hypertensive } \\
(\mathrm{n}=3,023)\end{array}$ & $\begin{array}{l}\text { Hypertensive } \\
(\mathrm{n}=2,733)\end{array}$ & $P$-value \\
\hline Sodium intake (g/day) [mean (SD)] & $3.20(1.35)$ & $3.17(1.36)$ & 0.462 \\
\hline Age in years [mean (SD)] & $38.32(13.57)$ & $51.28(14.69)$ & $<0.001$ \\
\hline Female $(\%)$ & $1874(47.0)$ & $1352(35.5)$ & $<0.001$ \\
\hline Ethnicity (\%) & & & $<0.001$ \\
\hline White & $1619(64.3)$ & $1416(65.7)$ & \\
\hline Latino & $1107(17.4)$ & $735(11.9)$ & \\
\hline Black & $830(12.2)$ & $1120(16.3)$ & \\
\hline Other & $382(6.2)$ & $268(6.1)$ & \\
\hline Education $(\%)$ & & & 0.12 \\
\hline Some school & $812(13.7)$ & $902(16.8)$ & \\
\hline High school degree & $946(24.3)$ & $940(26.5)$ & \\
\hline Higher education & $2180(62.0)$ & $1697(56.7)$ & \\
\hline Body mass index $\left(\mathrm{kg} / \mathrm{m}^{2}\right)$ & $29.56(6.65)$ & $32.41(7.35)$ & $<0.001$ \\
\hline [mean (SD)] & & & $<0.001$ \\
\hline Normal & $1008(27.5)$ & $397(12.6)$ & \\
\hline Overweight & $1263(32.3)$ & $1029(30.0)$ & \\
\hline Obesity Class 1 & $914(23.0)$ & $987(28.2)$ & \\
\hline Obesity Class 2 & $435(9.9)$ & $560(14.4)$ & \\
\hline Obesity Class 3 & $318(7.3)$ & $566(14.7)$ & \\
\hline Diabetes $(\%)$ & $234(3.8)$ & $827(18.1)$ & $<0.001$ \\
\hline Smoking (\%) & & & $<0.001$ \\
\hline Never smoker & $2287(59.1)$ & $1813(51.2)$ & \\
\hline Past smoker & $680(18.1)$ & $1030(28.4)$ & \\
\hline Current smoker & $971(22.7)$ & $696(20.4)$ & \\
\hline
\end{tabular}


medRxiv preprint doi: https://doi.org/10.1101/2020.12.27.20248919; this version posted January 2, 2021. The copyright holder for this preprint (which was not certified by peer review) is the author/funder, who has granted medRxiv a license to display the preprint in perpetuity.

It is made available under a CC-BY 4.0 International license.

Daily energy expenditure (Kcal)

$3450.90(1867.56)$

$3381.06(1809.72)$

0.314

Sample sizes (n) are unweighted. Means and prevalences are weighted but not adjusted by age.

NHANES 2007-2018 participants aged 20-79 years old on caloric restriction (-350Kcal/day) were included; people with active thyroid pathology, malnutrition, and pregnant women were excluded.

Hypertension was defined as mean systolic blood pressure $\geq 130 \mathrm{mmHg}$, mean diastolic blood pressure $\geq 80 \mathrm{mmHg}$, or self-reported use of hypertensive medication. Two-tailed $P$-values derive from weighted t-tests for continuous variables and the Rao-Scott F-adjusted $\chi 2$ test for categorical variables.

1

2 
medRxiv preprint doi: https://doi.org/10.1101/2020.12.27.20248919; this version posted January 2, 2021. The copyright holder for this preprint (which was not certified by peer review) is the author/funder, who has granted medRxiv a license to display the preprint in perpetuity.

It is made available under a CC-BY 4.0 International license .

1 Table 2. Survey-featured multivariable logistic regression model for the relationship between average daily sodium intake

2 (grams per day) and hypertension among U.S. adults in caloric restriction, aged 20-79. National Health and Nutrition

3 Examination Survey (NHANES) 2007-2018

Complete

case

analysis $\quad$ Multiple

Odds Imputations

\begin{tabular}{|c|c|c|c|c|c|}
\hline Variable & Units & Ratio & CI 95\% & Odds Ratio & CI $95 \%$ \\
\hline Sodium intake & g/day & $0.97 \dagger$ & {$[0.90 ; 1.05]$} & $0.97 \dagger ¥$ & {$[0.90 ; 1.05]$} \\
\hline Age & Years & 1.06 & {$[1.05 ; 1.07]$} & 1.06 & {$[1.05 ; 1.07]$} \\
\hline \multirow[t]{2}{*}{ Gender } & Male & Ref & & & \\
\hline & Female & 0.57 & {$[0.46 ; 0.70]$} & 0.57 & {$[0.46 ; 0.70]$} \\
\hline \multirow[t]{4}{*}{ Ethnicity } & White & Ref & & & \\
\hline & Latino & 0.76 & {$[0.62 ; 0.94]$} & 0.77 & {$[0.62 ; 0.95]$} \\
\hline & Black & 1.58 & {$[1.31 ; 1.91]$} & 1.58 & {$[1.31 ; 1.92]$} \\
\hline & Other & 1.24 & {$[0.90 ; 1.70]$} & 1.23 & {$[0.90 ; 1.69]$} \\
\hline \multirow[t]{4}{*}{ Education } & Some School & Ref & & & \\
\hline & High School & 0.9 & {$[0.68 ; 1.19]$} & 0.9 & {$[0.68 ; 1.18]$} \\
\hline & Higher & 0.87 & {$[0.68 ; 1.11]$} & 0.86 & {$[0.67 ; 1.1]$} \\
\hline & Education & & & & \\
\hline \multirow[t]{8}{*}{ Body mass index } & Normal & Ref & & & \\
\hline & Overweight & 1.39 & {$[1.07 ; 1.79]$} & 1.37 & {$[1.06 ; 1.76]$} \\
\hline & Class 1 & 2.09 & {$[1.58 ; 2.76]$} & 2.09 & {$[1.59 ; 2.75]$} \\
\hline & obesity & & & & \\
\hline & Class 2 & 2.18 & {$[1.59 ; 2.98]$} & 2.16 & {$[1.58 ; 2.94]$} \\
\hline & obesity & & & & \\
\hline & Class 3 & 3.76 & {$[2.56 ; 5.53]$} & 3.80 & {$[2.59 ; 5.58]$} \\
\hline & obesity & & & & \\
\hline \multirow[t]{2}{*}{ Diabetes } & No & Ref & & & \\
\hline & Yes & 1.83 & {$[1.36 ; 2.47]$} & 1.84 & {$[1.37 ; 2.47]$} \\
\hline
\end{tabular}


medRxiv preprint doi: https://doi.org/10.1101/2020.12.27.20248919; this version posted January 2, 2021. The copyright holder for this preprint (which was not certified by peer review) is the author/funder, who has granted medRxiv a license to display the preprint in perpetuity.

It is made available under a CC-BY 4.0 International license .

Smoking

Never smoker Ref

Past smoker $\quad 1.05$

1.05

Current

0.88

[0.71;1.10]

0.89

[0.72;1.10]

smoker

Energy Expenditure

Per 1,000 Kcal 1.03

[0.97;1.09]

1.03

[0.97;1.09]

Pseudo $\mathrm{R}^{2}$ (Cox-Snell)

0.217

Archer-Lemeshow test

0.83

AUC

0.777

$\dagger$ Adjusted by age, gender, ethnicity, education, body mass index, diabetes, smoking, and total daily energy expenditure.

$¥$ Pooled estimate of 20 imputed datasets using Rubin’s rules. Each dataset contained approximately 6,326 observations.

Caloric restriction was defined as an energy balance equal to or below $-350 \mathrm{Kcal}$ on an average day. Systolic and diastolic hypertension were defined as mean systolic and diastolic blood pressure values of $\geq 130 \mathrm{mmHg}$ and $\geq 80$ $\mathrm{mmHg}$, respectively. Hypertension was defined as either systolic or diastolic hypertension or self-reported use of hypertensive medication. CI: Confidence intervals using sample weights provided by NHANES (account for sampling design and dietary variation), strata, and unit. AUC: Area under the curve. 
medRxiv preprint doi: https://doi.org/10.1101/2020.12.27.20248919; this version posted January 2, 2021. The copyright holder for this preprint (which was not certified by peer review) is the author/funder, who has granted medRxiv a license to display the preprint in perpetuity.

It is made available under a CC-BY 4.0 International license.

Table 3. Survey-featured multivariable logistic regression model for the relationship between "high" and "low" daily sodium intake (threshold: $\geq 2.3$ grams per day) and hypertension among U.S. adults in caloric restriction, aged 20-79 (National Health and Nutrition Examination Survey 2007-2018, complete-case, multiple imputations, and matched using the propensity score of the exposure.

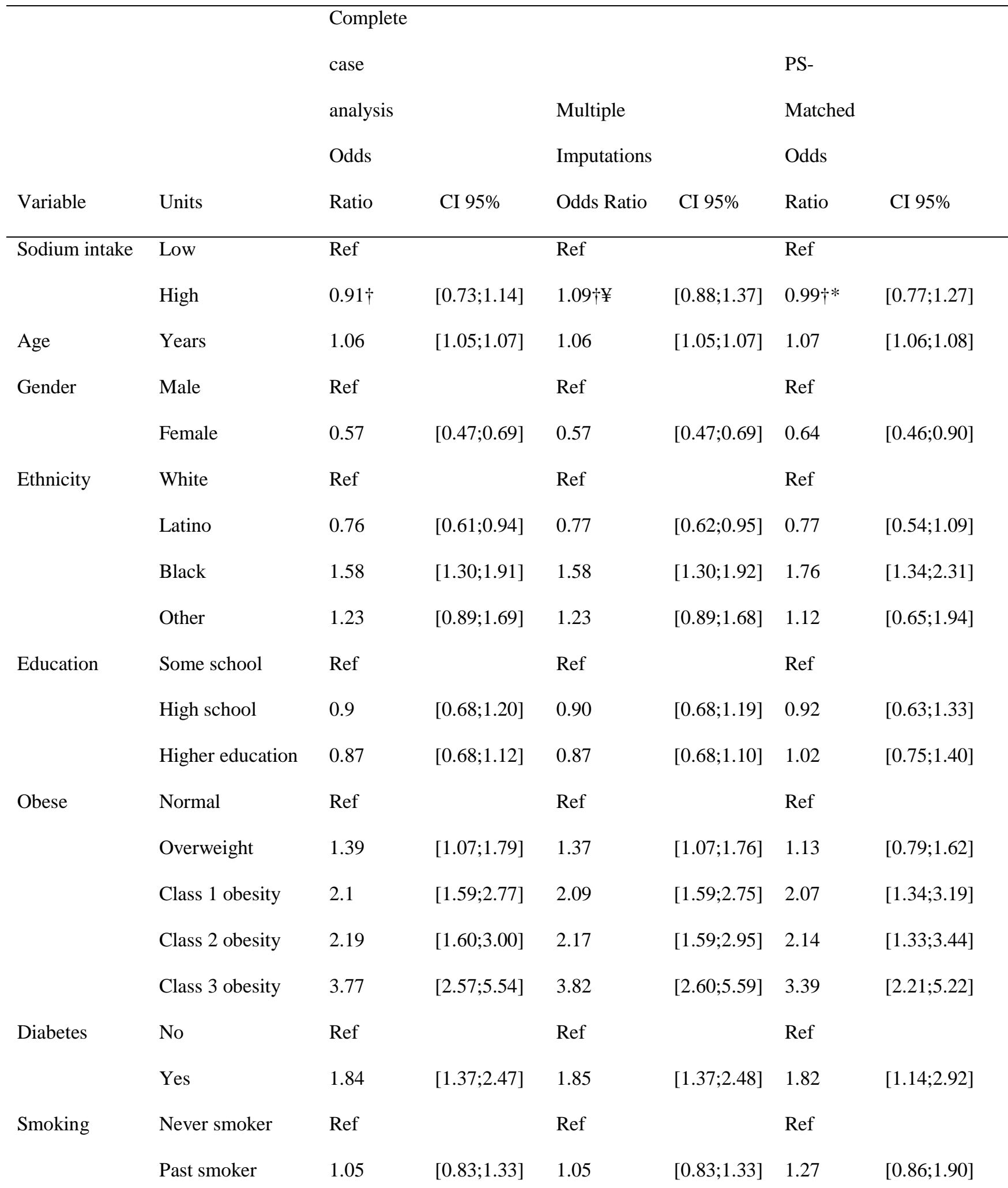


medRxiv preprint doi: https://doi.org/10.1101/2020.12.27.20248919; this version posted January 2, 2021. The copyright holder for this preprint (which was not certified by peer review) is the author/funder, who has granted medRxiv a license to display the preprint in perpetuity.

It is made available under a CC-BY 4.0 International license .

\begin{tabular}{|c|c|c|c|c|c|c|c|}
\hline & Current smoker & 0.88 & {$[0.71 ; 1.10]$} & 0.89 & {$[0.71 ; 1.10]$} & 0.88 & {$[0.63 ; 1.23]$} \\
\hline TDEE & $1,000 \mathrm{Kcal}$ & 1.02 & {$[0.97 ; 1.08]$} & 1.03 & {$[0.97 ; 1.09]$} & 1.03 & {$[0.96 ; 1.11]$} \\
\hline \multicolumn{2}{|c|}{ Pseudo R2 (Cox-Snell) } & 0.217 & & - & & 0.21 & \\
\hline \multicolumn{2}{|c|}{ Archer-Lemeshow test } & 0.63 & & - & & 0.478 & \\
\hline \multicolumn{2}{|c|}{ Area Under the Curve } & 0.777 & & - & & 0.797 & \\
\hline
\end{tabular}

$\dagger$ Adjusted by age, gender, ethnicity, education, body mass index, diabetes, smoking, and total daily energy expenditure.

$¥$ Pooled estimate of 20 imputed datasets using Rubin’s rules. Each dataset contained approximately 6,326 observations.

* Matched by exposure on 2,808 observations (1:1) using all adjustment variables plus survey features as covariates. Caloric restriction was defined as an energy balance equal to or below $-350 \mathrm{Kcal}$ on an average day. Systolic and diastolic hypertension were defined as mean systolic and diastolic blood pressure values of $\geq 130 \mathrm{mmHg}$ and $\geq 80$ $\mathrm{mmHg}$, respectively. Hypertension was defined as either systolic or diastolic hypertension or self-reported use of hypertensive medication. CI: Confidence intervals using sample weights provided by NHANES (account for sampling design and dietary variation), strata, and unit. 
medRxiv preprint doi: https://doi.org/10.1101/2020.12.27.20248919; this version posted January 2, 2021. The copyright holder for this preprint (which was not certified by peer review) is the author/funder, who has granted medRxiv a license to display the preprint in perpetuity.

It is made available under a CC-BY 4.0 International license.

1 Table 4. Survey-featured multivariable logistic regression model for the relationship between "high" and "low" daily

2 sodium intake (threshold: $\geq 5.0$ grams per day) and hypertension among U.S. adults in caloric restriction, aged 20-79

3 (National Health and Nutrition Examination Survey 2007-2018), complete-case, multiple imputations, and matched using

4 the propensity score of the exposure.

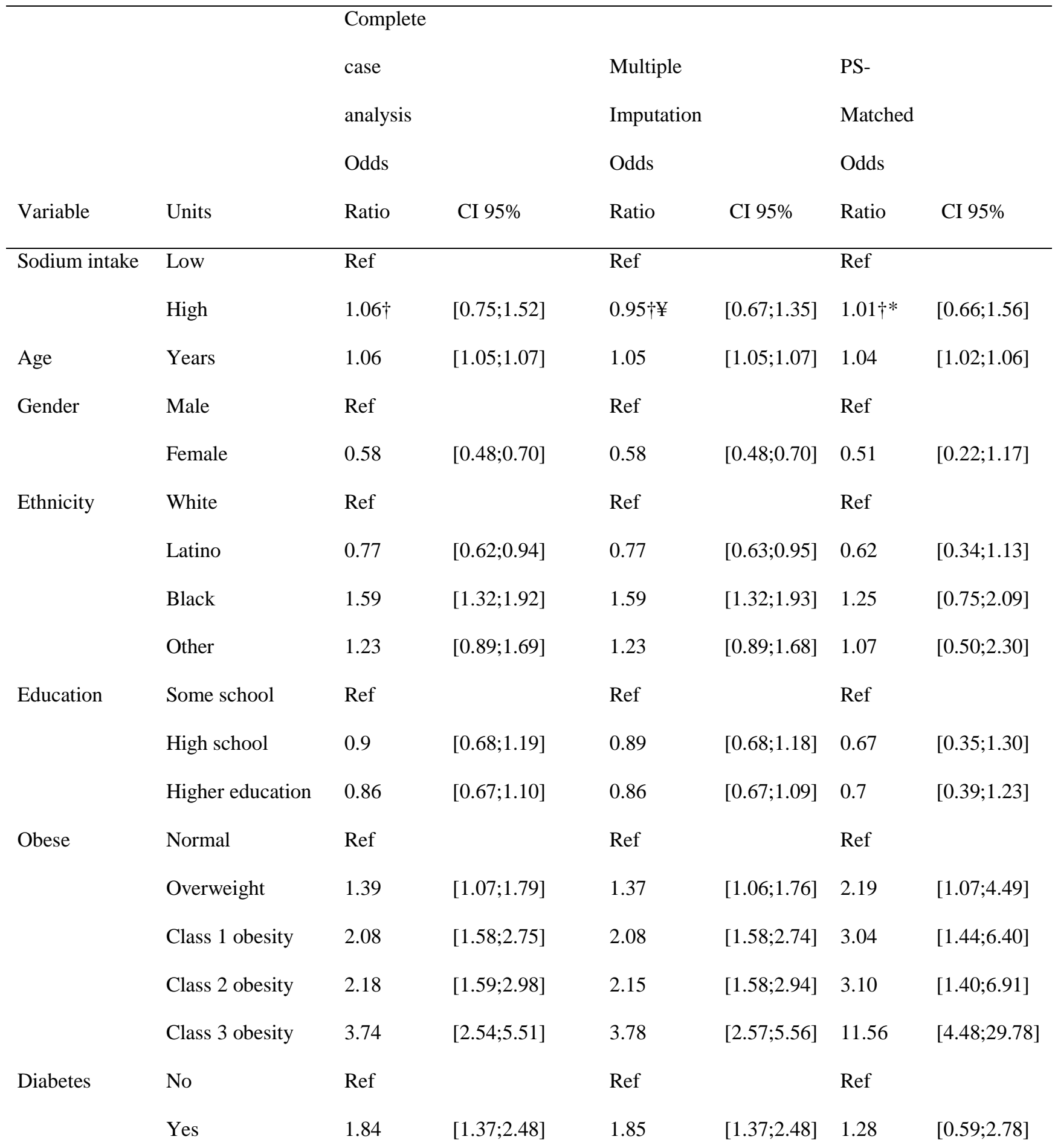


medRxiv preprint doi: https://doi.org/10.1101/2020.12.27.20248919; this version posted January 2, 2021. The copyright holder for this preprint (which was not certified by peer review) is the author/funder, who has granted medRxiv a license to display the preprint in perpetuity.

It is made available under a CC-BY 4.0 International license.

\begin{tabular}{|c|c|c|c|c|c|c|c|}
\hline \multirow[t]{3}{*}{ Smoking } & \multirow{2}{*}{$\begin{array}{l}\text { Never smoker } \\
\text { Past smoker }\end{array}$} & \multicolumn{2}{|l|}{ Ref } & \multicolumn{2}{|l|}{ Ref } & \multicolumn{2}{|l|}{ Ref } \\
\hline & & 1.05 & {$[0.83 ; 1.32]$} & 1.05 & {$[0.83 ; 1.33]$} & 0.85 & {$[0.47 ; 1.56]$} \\
\hline & Current smoker & 0.88 & {$[0.71 ; 1.10]$} & 0.89 & {$[0.72 ; 1.10]$} & 0.87 & {$[0.47 ; 1.61]$} \\
\hline TDEE & $1,000 \mathrm{KCal}$ & 1.02 & {$[0.96 ; 1.08]$} & 1.02 & {$[0.96 ; 1.08]$} & 0.99 & {$[0.91 ; 1.07]$} \\
\hline \multicolumn{2}{|c|}{ Pseudo R2 (Cox-Snell) } & 0.216 & & - & & 0.15 & \\
\hline \multicolumn{2}{|c|}{ Archer-Lemeshow test } & 0.89 & & - & & 0.47 & \\
\hline \multicolumn{2}{|c|}{ Area Under the Curve } & 0.777 & & - & & 0.73 & \\
\hline
\end{tabular}

$\dagger$ Adjusted by age, gender, ethnicity, education, body mass index, diabetes, smoking, and total daily energy expenditure.

$¥$ Pooled estimate of 20 imputed datasets using Rubin’s rules. Each dataset contained approximately 6,326 observations.

* Matched by exposure on 926 observations (1:1) using all adjustment variables plus survey features as covariates.

Caloric restriction was defined as an energy balance equal to or below $-350 \mathrm{Kcal}$ on an average day. Systolic and diastolic hypertension were defined as mean systolic and diastolic blood pressure values of $\geq 130 \mathrm{mmHg}$ and $\geq 80$ $\mathrm{mmHg}$, respectively. Hypertension was defined as either systolic or diastolic hypertension or self-reported use of hypertensive medication. CI: Confidence intervals using sample weights provided by NHANES (account for sampling design and dietary variation), strata, and unit. 
medRxiv preprint doi: https://doi.org/10.1101/2020.12.27.20248919; this version posted January 2, 2021. The copyright holder for this preprint (which was not certified by peer review) is the author/funder, who has granted medRxiv a license to display the preprint in perpetuity.

\section{It is made available under a CC-BY 4.0 International license .}

\section{Figures}

\section{Figure 1.}

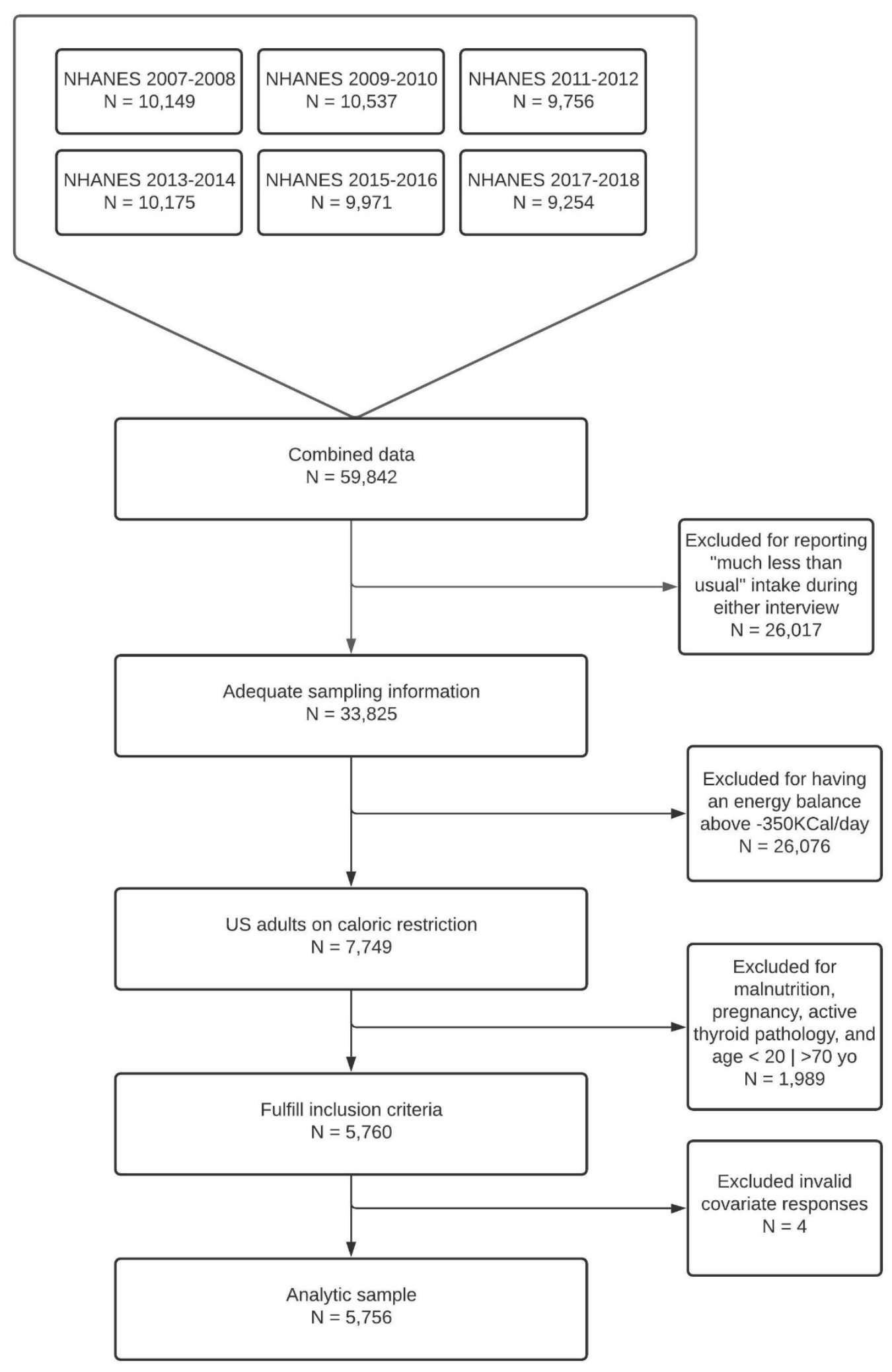


medRxiv preprint doi: https://doi.org/10.1101/2020.12.27.20248919; this version posted January 2, 2021. The copyright holder for this preprint (which was not certified by peer review) is the author/funder, who has granted medRxiv a license to display the preprint in perpetuity.

\section{It is made available under a CC-BY 4.0 International license .}

Figure 2.

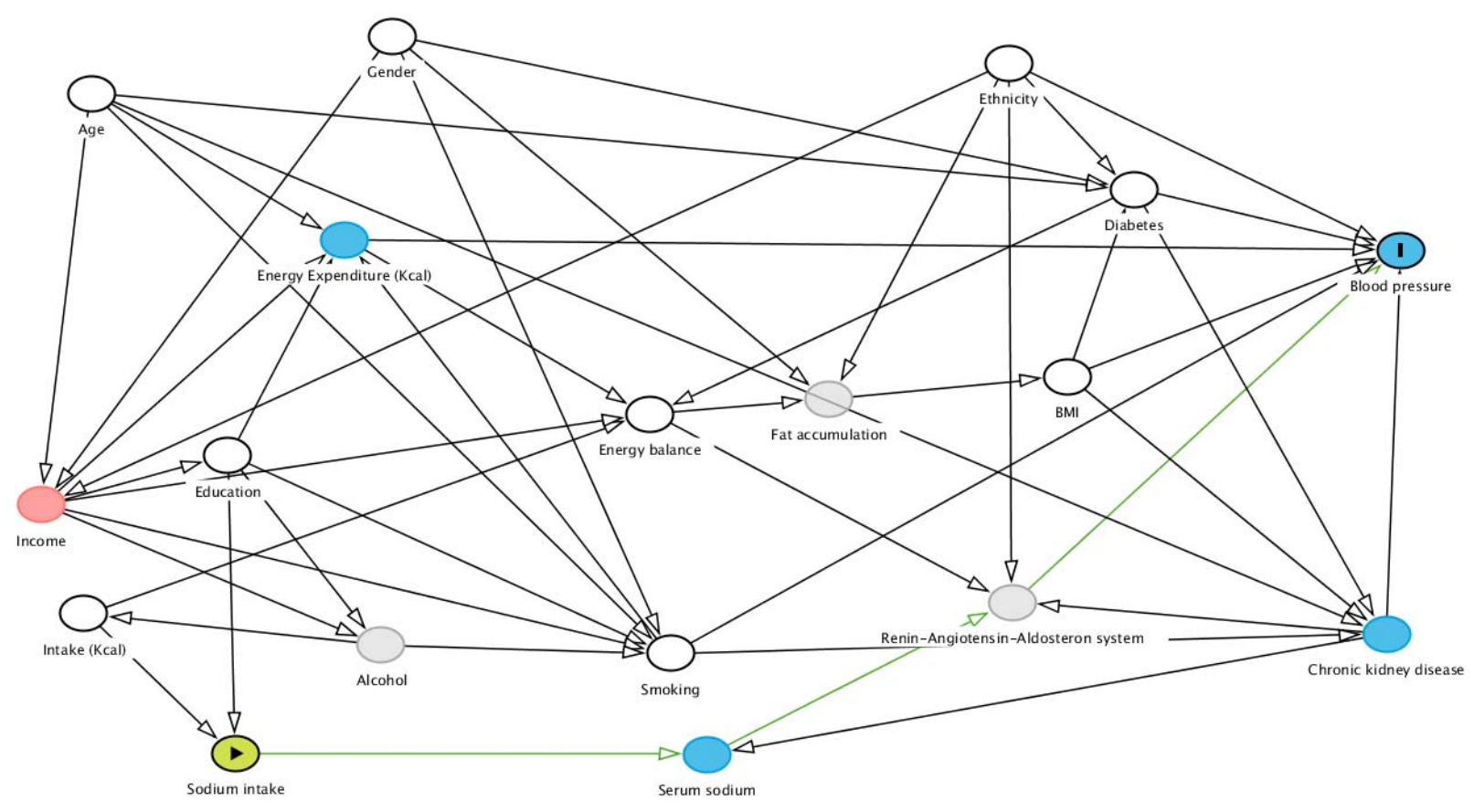

